\title{
Education, Political Awareness, and Political Participation: A Case of Rahim Yar Khan District of Pakistan
}

\author{
Nayar Rafique \\ Air University, Islamabad, Pakistan \\ nayyar.rafique@aack.au.edu.pk \\ nayarrafique_13@pide.edu.pk
}

Received: September 2, 2021. Revised: September 27, 2021. Accepted: October 1, 2021. Published: October 4, 2021.

\begin{abstract}
By acknowledging the quality of individuals as an important parameter for the socio-economic and political development of a society, this study has attempted to examine the quality of political choices made by the resident of the massively uneducated district Rahim Yar Khan in Punjab province of Pakistan. The persistence of an inefficient and fruitless political status quo of few influential political families and the existence of a massive uneducated population cast doubts over the quality of political choices made by the residents of Rahim Yar Khan. By centralizing analysis around education, this study assessed political awareness and the extent to which individuals are willing to participate in the political process. A total of 404 respondents with varying educational levels from $\mathbf{4 2}$ union councils, systematically selected from the whole district, were examined. The findings of this study revealed a shockingly poor state of political awareness and higher willingness of political participation for the individuals with no and lower level of education. This poor awareness then explains the persistence of the inefficient political status quo of few families without any value and hence causing chronic damage to political as well as socio-economic profile of Rahim Yar Khan.
\end{abstract}

Keywords: Education, Institutions, Political Participation, Political Awareness, Development

\section{INTRODUCTION}

Rahim Yar Khan is Punjab's fourth-largest district by area with total jurisdiction of 1180 square kilometers. It was a part of Bahawalpur State until 1943 when it was declared a separate district of Punjab. The district is primarily a Muslim neighborhood, with Hindus, Christians, Ahmadis, Scheduled Castes, and other religious groups. According to the 2017 population census, the district is ranked sixth in Punjab by population. The district contains 0.7 million dwellings under a population density of 405.22 square kilometers, carrying a total population of 4.81 million, residing in urban and rural areas. The sex ratio of Rahim Yar Khan's population mix is 105.2, with $48.7 \%$ women and $51.3 \%$ men. Rural areas make up 78.5 percent of the population, while urban areas make up 21.5 percent. The total population of the district increased by 2.27 percent between 1998 and 2017. The children-dependent population (up to 15 years of age) accounts for 46.1 percent of the total population, with 24.2 percent men and 21.9 percent females. The working-age population in the age category 15 64 years accounts for 50.6 percent of the overall population, with 26.1 percent men and 24.5 percent women. The old dependent population accounts for 3.2 percent of the total population, with 1.7 percent males and 1.5 percent females. Young people (15-35 years old) account for 31.3 percent of the total population. The overall dependency ratio is 97.44 dependents per 100 working adults, including 91.1 children (0-14) and 6.3 elderly (64+). Thirty-six percent of people aged ten and more are economically active, whereas sixty-four percent are economically inactive for various reasons. Twenty-nine percent out of the total active population are employed, and seven percent are unemployed. When we look at adults aged 25 to 59 , the number of economically active people climbs to $44 \%$, with $40 \%$ employed and $4 \%$ unemployed. Eighty percent of the working population is employed in agriculture, while twenty percent is employed in services and industry (PBS, 2017).

Rahim Yar Khan is an active player in national politics, having 6 National Assembly seats and 22 provincial assembly seats when it comes to political dynamics. Makhdoom, Syed, Choudhary, Warraich, Gujjar, Mian, and other families dominate district politics. The Makhdoom family is the most powerful, having ruled on from the platforms of different political parties since 1956. According to the official records, the dominant families from Rahim Yar Khan had a strong political presence in the federal and provincial legislature with all influential ministerial portfolios from 1950s to 2018 (National-Assembly-Pakistan, 2021; GOP, 2021). In addition to holding ministries, politicians from Rahim Yar Khan also remained in power regimes through secretarial and advisory roles with key personalities such as Prime Minister, President, and chief ministers. Some of the influential politicians also served as opposition leaders and chairs in various institutions. In conclusion, with powerful political representation, Rahim Yar Khan's political elite 
remained a vital element of every democratic and military rule in Pakistan.

By attributes, Rahim Yar Khan's political class shares two traits. First, they all belong to distinct types of elites who have little interest in serving the commons or working to improve their constituents. Second, despite having power, influence, and riches, successive generations of the same families maintain political posts and share the same elitist mindset toward serving the common good. The result is that, despite having a significant participation in practically every province and national legislature from 1956 to 2018, the Rahim Yar Khan political class failed to deliver on social, economic, and political fronts.

By socio-economic status, Rahim Yar Khan falls in the least developed districts of Punjab. According to the Pakistan Human Development Report, Rahim Yar Khan is the fourth-worst district in Punjab concerning district level Human Development and Multidimensional Poverty (UNDP, 2017). With an average intensity of $51 \%$, more than half of the total population $(56.8 \%)$ is facing multidimensional poverty. Confirmed by the presence of sixty-seven percent of uneducated adults and thirty percent of the schooling age children out of the school, the education-related poverty accounts for 45.6 percent, putting Rahim Yar Khan in the second-worst place in Punjab regarding education (GOP, 2017; UNDP, 2017). The situation of education in Rahim Yar Khan is ascribed to a combination of resource, infrastructure, and political constraints, proving the state's incapacity to offer sufficient quantity and quality of education to the district's nearly 5 million citizens.

Rahim Yar Khan is Punjab's second-worst district for underweight children in the age 0-5 years, third-worst district for stunted growth, and second-worst district for wasting prevalence rate, behind D.G. Khan. According to this data, the child death rate in Rahim Yar Khan is 109 per 1000 births, while the mortality rate for the newborn is 85 for everyone thousand births. Adult health indicators are also not as good as possible due to a higher number of disease incidences than in other parts of Punjab province (GOP, 2017). If we look at the health infrastructure, the situation is as gloomy as the health conditions: the whole district has only eight public sector hospitals, two tuberculosis clinics, 64 dispensaries, nine rural hospitals, 107 primary health facilities, and seven mother and child health centers to serve a population of 4.8 million (GOP, 2017). This whole situation confirms the persistence of $25.1 \%$ health deprivation according to the multidimensional poverty index (UNDP, 2017).

Similar to other indicators, the state of law and order is also poor at Rahim Yar Khan. According to GOP (2016), $7 \%$ of all crimes perpetrated in the province belong to the Bahawalpur division ${ }^{1}$. Rahim Yar Khan is linked to 42 percent of all crimes in the Bahawalpur division, including 41 percent of murders, 36 percent of attempted murders, 44.08 percent of wounded cases, 46 percent of assault cases, and 35 percent of all rape cases. Aside from that, Rahim Yar Khan is to blame

${ }^{1}$ Having three districts i.e., Rahim Yar Khan, Bahawalnagar, and Bahawalpur for $75 \%$ of all riot cases in the Bahawalpur division (GOP, 2016).

Given the weak socio-economic profile, the dilemma facing Rahim Yar Khan is a relentlessly inefficient political status quo explained by a firm control of few families over the politics/political system without any substantial contribution to the growth and development. When seen in the context of the massive illiterate population, this persistent political status quo seems to be an outcome of broader ignorance that prevails among uneducated citizens. With this assumption, the strength of the political status quo, the political system's inefficiency, and low development may well be explained through the quality of political choices repeatedly made by massive uneducated individuals.

With this argument, we assume individuals with legitimate voting rights are mainly responsible for the political system's general inefficiency and a stronghold of few families on the political landscapes of Rahim Yar Khan. In line with the assumption, the study has attempted to analyze the quality of individual political choices by looking at the political awareness and willingness to participate in the political system of individuals with varying educational levels. The aim of this analysis is to find the linkages of massive educational deprivation with the inefficient and fruitless political status quo.

\section{THE IMPORTANCE OF INDIVIDUAL}

A political system is a complex mix of the concept and ideas like voters, elections, political leaders, government, policies, and many more. Politics, on the other hand, is definable as the act of involving certain people or stakeholders in interactions for a specific activity, which represents a network that is public operating through various political institutions and deals with bargains, solutions, controversies, settlements, and public questions. Generally, public questions are known as political questions/political issues/public issues are inquiries into public concerns and the legislative decisionmaking mechanism that influences such matters. Some of the common political questions in democratic states are related to structure, allocation, and utilization of authority in a state. These questions mainly concern the governance mechanism to exploit political authority; the aims as to which power is apportioned to authorities; the manner in which power and authority are exercised by the government; what entails ruling class; and the mechanism through which a political party or elite gain authority. In addition, the public questions also concern the use of authority by keeping in mind the benefit of the entire society. It also entails a mechanism to prevent the governing political class from abusing their power; and various other issues relating to the political system. In conclusion, the political system corresponds to the political process involving various political institutions and stakeholders. In democratic states, some of the political stakeholders gain legitimate political authority through a legitimate political process that involves consideration of public choices through voting. Those who gain authority then represent their legitimate political domain for the creation, enforcement, and application of laws through various political 
institutions. They typically mediate disagreements, formulate government economic and social policy, and represent the general public in a variety of ways.

The literature extensively emphasizes that a society's socio-economic growth is directly linked to the quality of political institutions it has built. Good laws, effective policies, the rule of law, the protection of property, and other settings favorable to development and growth are created through inclusive and stable democratic institutions. Extractive and unstable political institutions, on the other hand, cause distortions and inefficiencies, hampering a state's growth and development (Conge, 1988; Robinson \& Acemoglu, 2012; Hooghe \& Quintelier, 2014). The health of political institutions determines their ability to impact growth and development, which is influenced by the quality of the political system, which is primarily determined by the quality of individuals involved in the political system (Robinson \& Acemoglu, 2012).

In light of the previous discussion, we believe that a political system's underlying strength and the quality of its institutions are largely described by the quality of political stakeholders active in the system. If the stakeholders involved are of poor quality, a poor quality, extractive, and weak political system are likely. On the other hand, if they are backed by high-quality political stakeholders, there will be a good likelihood of a strong, inclusive, and productive political system and political institutions. A lot of economic, social, and political factors involves in explaining the political quality of stakeholders involved in the political system. Among all, the extent to which a society is educated outweighs all other factors. Education, a transformative force, influences the formation and growth of capabilities through the influence of individuals' Political Awareness inducing free will in political involvement or participation. Fundamentally, Political participation has a significant impact on an individual's political quality. Basically, education plays a huge role in political capability enhancement, which improves an individual's quality, thereby making lack of education constrains capabilities and thus diminishes individual quality.

The high-quality individuals with the necessary information and skills set to comprehend the advanced political environment, the interactions of stakeholders in politics, the process of politics, beneficiaries, outcomes of politics, and political system responses created for development and growth are provided through education (Berinsky \& Lenz, 2011; Robinson \& Acemoglu, 2012; OSTROM, 2015). Collectively, political dynamics understanding demonstrates how aware people are of the abstract nature of politics, its related political questions, stakeholders, and process, reflects their alertness in making effective political decisions (Rosenstone \& Hansen, 1993; Verba, Schlozman, \& Brady, 1995; Dee, 2004; Tenn, 2007; Kam \& Palmer, 2008; Sondheimer \& Green, 2010). Furthermore, education builds capacity through facilitating political participation by offering possibilities for leadership and various forms of political participation. Individuals' willingness to participate in the political process is influenced by education in this way (Berinsky \& Lenz, 2011; Deth, 2014).

\section{DATA AND METHODOLOGY}

In line with the dilemma facing Rahim Yar Khan, this study attempted to analyze the political quality of individuals with varying educational levels by looking at the political awareness and willingness to participate in the political system. The entire analysis is carried with the help of primary data of persons with varying educational levels, collected from four subdistricts of Rahim Yar Khan by using a post and pretested, comprehensive questionnaire based on a purposive sampling technique under multi-level basis, with the aim of including people of any given educational levels. The primary unit of analysis was a person being in the age bracket of 25-59 years, enrolled as a wage worker, and has gained any of the seven levels of education. These requirements were put in place to ensure that people with educational levels ranging from 0 to 6 were included. The age of twenty-five was chosen as a natural starting point for this study because it is at this age that a person can possibly achieve the highest degree of education (16+) in Pakistan. The education-wise proportion of the female and male economically active population has been drawn from the district census report for the age group 25-59 in the light of the sampling frame for this study. A total of 421 respondents were surveyed with a 95 percent confidence interval by a well-trained surveyor, according to the proportions explained in Appendix Table 1. The sample utilized for Rahim Yar khan was determined using the following criteria: the individuals questioned were picked from 42 local administrative jurisdictions called union councils. The selection of union council has been made systematically to cover the whole district with four subdistricts ${ }^{2}$ : every third union council from a sorted list of total 122 union councils, as shown in the Appendices Table 2, has been selected for survey.

The recruitment of respondents within each union council is based on convenience sampling as financial and other constraints did not permit an utterly randomized selection at this stage. The recruitment process involved consideration of ten individuals from each union council which fits the sampling frame explained earlier and suites the requirements of this research. A few necessary steps in this regard were followed to ensure the inclusion of the right candidate for the survey. A hit and trial method has been adopted to survey ten persons from each union council by relying on personal observation and pre-survey screening interviews. Furthermore, the survey was conducted by ensuring the inclusion of male as well as female respondents according to the sample chart, explained in Appendix Table 1. First, based on personal observation about the suitability of research, a screening review has been carried to confirm age (25-59), working status (earner), schooling (one of the six levels in addition to respondent consent (willingness to participate) for the survey. If the respondent fits in the

${ }^{2}$ Rahim Yar Khan, Sadiqabad, Khanpur, Liaqatpur 
sampling frame after the screening, the survey was conducted; if the individual refused to take part or does not fit in the sampling frame, the review process was repeated with another individual until we had data from 10 individuals from each union council according to the sampling frame. By using this mechanism, a total of 421 responses were collected. After post-data collection screening, the data of 404 individuals has been found appropriate to proceed with the main analysis of this study.

For effective data collection, a tailored questionnaire was created in light of the literature. In order to ensure order, precision, and clarity, a conventional survey framework was deployed, with increased emphasis on the sequencing besides the language and definition of the questions (Bryman, 2016). It entailed questions with varied scales of ordinal for the assessment of political knowledge and political participation, the two major areas of assessment for this study, in addition to general classification questions.

Two facets of Political Awareness have been assessed to test the political knowledge of individuals at various levels of education. They include awareness of the political representatives and awareness of the overall political system. A survey of people's knowledge of political representatives was carried to analyze how well aware people in Rahim Yar Khan are about their political representatives. The respondents were asked for the Name, Education, Profession, and Political Party of the seven key political representatives. These seven representatives are divided into two categories: local representatives of Rahim Yar Khan (District Chairman, U.C. Chairman, MPA, MNA) and national level representatives (President of Pakistan, Prime Minister of Pakistan, and Chief Minister Punjab). The goal of assessing this level of awareness was to see how familiar people are with the profiles of political representatives they have elected at various levels. Respondent awareness score, ranging from zero to four, for this, was established in accordance with the goal based on the correct responses they provided ${ }^{3}$. A respondent can maximum achieve an awareness score of 28 if that respondent answers all four attributes correctly for all seven representatives. Whereas in the case of all wrong answers, the awareness score stands out to be zero. With this mechanism, an awareness value for political representatives is computed by the taking the ratio of difference between obtained and minimum scores (Obtained APR- Min APR) to the difference of maximum and minimum APR scores (Max APR- Min APR).

Individuals' understanding of the political system was used to assess how well they thought about key parts of Pakistan's political system. A bunch of seventeen question, as given in Appendices Table 3, were presented to the respondents tending to the important stakeholders, composition of the poloitical system, and some practical sttribuites to survey people's familiarity with the general political framework on a dichotomous scale $(0,1)$. Respondents were offered one point for each right response and 0 focuses for each inaccurate answer. Utilizing these

${ }^{3} 0$ if respondent knew nothing, 1 if he knew only one and so on 4 if he knew all four attributes for a representative. answers, a total worth, addressing a specific respondent's mindfulness with the political framework, was determined by taking the apportion of right reactions to the complete number of inquiries (17). Because of the methodology illustrated, each of the 421 respondents had their political information on the political framework surveyed (with 404 proper reactions). Like the qualities in the main stage, this made qualities in the zero to one territory. The qualities more like one demonstrate a more significant level of mindfulness, while values more like 0 show a lower level of mindfulness for the two types of mindfulness. At last, by averaging the two mindfulness scores with equivalent loads, a total worth of political mindfulness was determined. In light of the mindfulness scores, an individual might can be categorized as one of the six classifications of mindfulness.

To assess the willingness to participate in the political system, we have classified political participation into conventional and unconventional modes in the light of literature. Assessment of conventional political participation involves evaluation of three modes of participation, i.e., willingness to vote, willingness to campaign for a candidate, and willingness to donate for political parties or political leaders (Kaase \& Marsh, 1979; Inglehart \& Catterberg, 2002; Pateman, 2012; Albacete \& Gema, 2014; Hooghe \& Quintelier, 2014; Deth, 2014). The study to analyze the extent to which individuals are willing to participate unconventionally has considered two modes of participation, i.e., targeted participation that involves participation in the political protests ( (Inglehart \& Catterberg, 2002; Teorell, 2010) and civic engagement that involves participation in the political system to engage with political authorities for the solutions of community problems ( (Zukin, Keeter, Andolina, Jenkins, \& Carpini, 2006; Hay, 2007; Conge, 1988). Thus, the willingness regarding three modes of conventional and two modes of unconventional political participation has been carried shown in the following Table 1:

Table 1. Items for Political Participation Assessment

\begin{tabular}{|c|c|}
\hline Category & Item \\
\hline \multirow{3}{*}{$\begin{array}{l}\text { Conventional } \\
\text { Participation }\end{array}$} & What chances are there for you to Vote in next elections? \\
\hline & $\begin{array}{l}\text { What chances are there for you to campaign in election for some } \\
\text { political party/leader? }\end{array}$ \\
\hline & What chances are there for you to donate for some political party/leader \\
\hline \multirow{2}{*}{$\begin{array}{l}\text { Unconventional } \\
\text { Participation }\end{array}$} & $\begin{array}{l}\text { What chances are there for you to participate in protest against political } \\
\text { issues? }\end{array}$ \\
\hline & $\begin{array}{l}\text { What chances are there for you to lead your community for conveying } \\
\text { political problems to the concerned political authorities? }\end{array}$ \\
\hline
\end{tabular}

\section{RESULTS AND DISCUSSION}

\section{Awareness}

Individuals' understanding of their political representatives and the entire political system was shockingly low, according to the assessment results for both elements of political awareness. A higher level of ignorance was revealed in the assessment of political representatives' awareness. The assessment result shows a higher level of ignorance for Local political officials than representatives of national stature, as shown in the following Figure 1: 


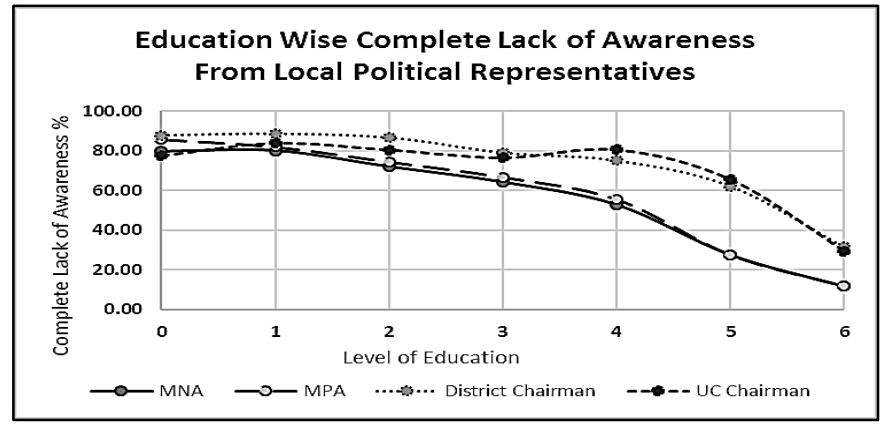

Fig. 1 Ignorance from political representative by education

Eighty-three percent of those with no education and eighty-four percent of those with the primary school had no idea who their local political representatives were. After primary school, the fraction of people who are completely ignorant ${ }^{4}$ starts to decline. The rate of complete ignorance falls to $79 \%$ for persons with level 2 education, $72 \%$ for level 3, $66 \%$ for level 4, 46\% for level 5, and $21 \%$ for level 6 . Although there is an increase in awareness as one's educational degree increases, twenty-one percent of those with the highest level of education remain utterly clueless. These findings revealed the highly educated class's lack of vigilance and logic, casting doubt on the quality of their political decisions at the national, provincial, and grassroots levels.

Overall, the low level of political awareness reveals people's inability to examine their political legislatures at every level in order to make effective and efficient political decisions. As shown in the graph, this difficulty decreases as education years grow, indicating the relevance of education in determining the quality of political decisions.

In comparison to local politicians at all levels of education, the data collected demonstrates that national political leaders have a significantly lower degree of ignorance. People with no schooling are the most oblivious to the four qualities of the President, Prime Minister (PM) of Pakistan, and Chief Minister (CM) of Punjab, as displayed in Table 2. As training levels expanded, the level of individuals who were totally ignorant diminished. By and large, political agents' degrees of mindfulness ascend from the base up. The abatement in obliviousness or ascend in mindfulness for the top political authorities, like the President, Prime Minister, and Chief Minister, could without much of a stretch be a media sway because of the ceaseless media openness of these top political characters. With his eminent recognition as a cricket player, philanthropist, and change-agent politician, the Prime Minister of Pakistan remained the most recognized political representative in this study, with $94 \%$ of the total individuals surveyed knowing at least one of the four attributes of the Prime Minister of Pakistan.

${ }^{4}$ Unaware of all four attributes (Name, Education, Profession, Political Party)
Table 2. Individuals unaware of all four attributes (\%)

\begin{tabular}{|c|c|c|c|}
\hline \multirow{2}{*}{ Level of Education } & \multicolumn{3}{|c|}{ National Representative } \\
\hline & President & Prime-Minister & Chief Minister Punjab \\
\hline Level 0 & 55 & 22 & 70 \\
\hline Level 1 & 52 & 7 & 46 \\
\hline Level 2 & 36 & 6 & 39 \\
\hline Level 3 & 35 & 7 & 29 \\
\hline Level 4 & 8 & - & - \\
\hline Level 5 & 7 & - & - \\
\hline Level 6 & - & - & - \\
\hline
\end{tabular}

Similar to the awareness of political representatives, the results with respect to the information on the political framework additionally drove us to a horrendous showcase of mindfulness at all degrees of instruction. Seventy-four percent of the total respondents were not aware of the total number of seats in Pakistan's National Assembly, whereas ninety-two percent were not aware of total provincial assembly seats. The state of awareness regarding district seat allocation is also extremely poor as ninety-two percent of the respondents were not aware of the total number of the national assembly and provincial assembly seats allocated in their own district, Rahim Yar Khan.

A similar poor display of awareness has been observed regarding the composition of the national assembly as ninety-three percent of total respondents were not aware of general and minority seats, whereas ninety-four percent could not answer rightly about the women reserve seats in the national assembly. The state of awareness for the questions related to key political stakeholders is also not impressive. Out of 404 responses, seventy-four percent were not aware of the name of Chairman Senate, sixty-eight percent were unaware of the name of the speaker in the previous national assembly, sixty-three percent could not answer the name of opposition leader in the previous national assembly, and sixty-two percent were unable to identify the name of the current governor of Punjab Province.

Analogous to the pattern of awareness regarding composition and stakeholders, the assessment of functional attributes also revealed a gloomy picture as ninety-one percent of the respondents were unable to answer correctly about the tenure of a senator, whereas 79 were unable to correctly answer the tenure of the member of the national assembly. Similarly, ninety-one percent were unable to tell the SMS code for voter information inquiry. Eighty-six percent of the total respondents were not able to answer rightly about the minimum age for a member of the national assembly. The only most known factor was the minimum age of a voter, but still, thirty-two percent of the total respondents could not answer this easy question as well. The data show that the majority of those surveyed were unaware of the makeup, main players, and functional characteristics of national politics. This lack of political structure awareness at all levels of education validates the poor quality of individual political choices in Rahim Yar Khan. To continue with our analysis, we calculated aggregate political awareness scores for each individual using the method described in the previous section, in view of their reactions to the two arrangements of inquiries, 
to reach some target inferences about their by and large political mindfulness dependent on their instructive level. As seen in the following Figure 2, both forms of political awareness have a positive relationship with an education based on the values determined:

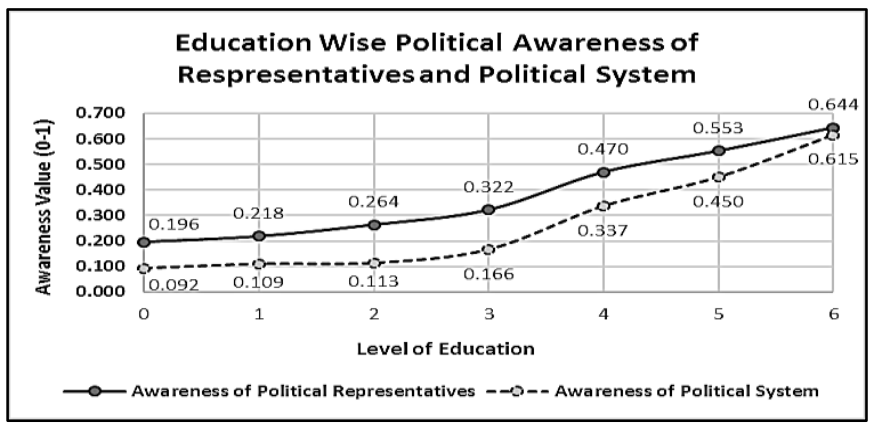

Fig. 2 Two variants of political awareness by education

At each level of education, awareness of political representatives demonstrates higher values than awareness of the political system. These findings suggest that with each degree of education, the individual knowledge of political representatives is comparatively higher. Individuals are less worried about the mechanics of the political system than they are about their own personalities, as evidenced by this pattern. It exposes a dangerous trend of making political decisions based on personal preferences rather than understanding the system. The awareness gap between the two types is visible at each level of education, and it narrows as education levels rise. Individuals with the highest education have political awareness that falls in the moderate awareness range, which is consistent with the form of two variants of Political Awareness. Nonetheless, the scope of qualities portrays a dull outcome, as people with the most elevated schooling, i.e., 16 or $16+$, have less than ideal political mindfulness. Moreover, there is no critical addition in the two forms of political mindfulness from level 0 to even out 2 , but the increase in awareness after eight years of schooling, or level three, is more significant. The aggregate value of Political Awareness, as depicted in Figure 3, follows the same pattern as the two versions of awareness. It shows a positive relationship between schooling years and overall political awareness, as well as a seamless transition in overall awareness from one level of education to the next.

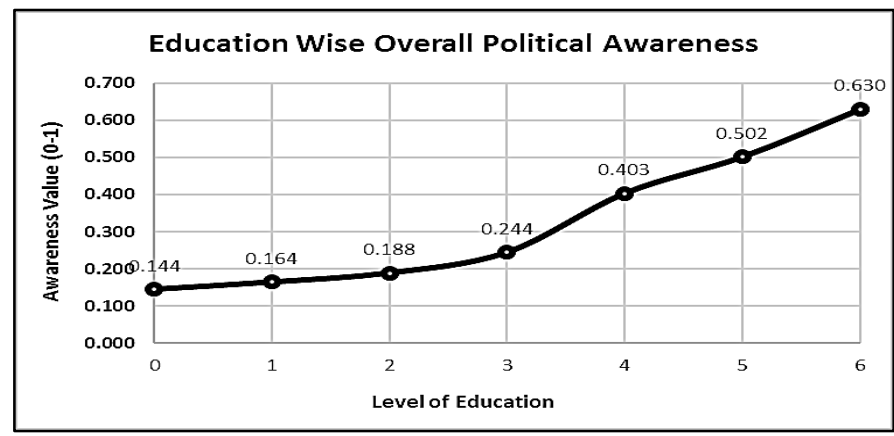

Fig. 3 Aggregate political awareness by education
The increase from $0-2$ level in total political awareness is not significant; the difference from zero to elementary schooling is exactly two percentage points. With a 2.4 percent increase in Political Awareness from elementary to middle school, there is a minor improvement. It demonstrates a $6 \%$ increase in political understanding from middle to matric (10 years). According to the data obtained, the greatest substantial change (16\%) occurs when education years change from 10 to twelve. The change in political consciousness from 12 to 14 years of education is positive $10 \%$, and the change in political awareness from 14 years to masters or above is positive $13 \%$. Summing up the whole discussion, In the Rahim Yar Khan district, an increase in education leads to an increase in individual political awareness.

\section{Participation}

Individual answers to three kinds of traditional political participation are summarized in Appendices Table 4 for entire educational levels. It shows a more noteworthy status among individuals of all instructive levels to take part in deciding in favor of the impending decisions. An amount of $79.59 \%$ of electors had level 0 instruction, 77.14 percent with level 1 schooling, 94 percent with level 2 training, 91 percent with level 3 schooling, 100\% with level 4 training, 86 percent with a level 5, and 91 percent with level 6 schooling said they would cast a ballot in the races. People's reactions to the second method of conventional political interest, in particular the possibility of crusading in a political decision for some ideological group/competitor, show bipolar conduct, with most of the responses falling between two limits, specifically no possibility of battling and high/distinct shots at crusading. Most of the respondents at all instructive levels communicated no interest in the third method of customary political support, specifically, giving to an ideological group or a political applicant/pioneer.

Appendices Table 5 summarizes the answers to two unconventional types of political participation. Individuals with no education had the highest possibility of participating in political protests, with 55 percent indicating that they intended to do so with the highest probability. This shows that persons with no education, with the least political awareness (awareness score 0.144), are more willing to participate in protests, which is concerning because such individuals might easily manipulate the political system. The results showed a gradual rise in the proportion of people who are more likely to participate in political protests from level 1 to level 6 . When asked about their possibilities of driving/addressing their networks to resolve political issues, the evaluation uncovered positive results, as confirmed by the expanded readiness of individuals of different instructive levels to partake in the political framework by driving their networks. As displayed in the appendices Table 5, 51 percent of respondents with level 0 preparing, 54 percent of respondents with level 1 guidance, 56 percent of respondents with level 2, 67 percent of respondents with level 3, 91 percent of respondents with level-4, 89 percent of respondents with level 5, and 82 percent of respondents with level-6 tutoring (16 years or higher) showed high expect to lead their local area. An aggregate political participation score has been determined to assess the overall 
participation for each level of education by averaging the conventional and unconventional participation scores. This joint participation score, as shown in the following figure, depicts a substantially higher willingness to participate by individuals with zero levels of education which fell for primary education, and then it rises again with educational as depicted in figure 4 :

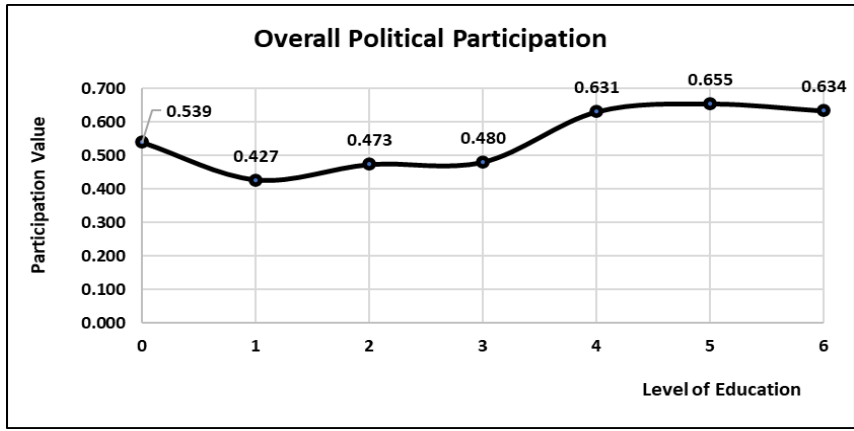

Fig. 4 Political participation by education

According to the assessment results, as shown in figure 4 , the individuals without education are more active participants in the political process. This participation is welcomed in the literature as a positive factor towards a strong political system, but for the societies like Rahim yar Khan, it raises serious concerns. Now the main question in this regard is to see whether a higher level of participation by uneducated people, however, is capable of producing meaningful/ efficient political outcomes? Is it a genuine, value-added engagement or merely a symbolic participation? To answer these questions, the study has further analyzed the political awareness and participation together, as discussed in the next section.

\section{Education and quality of political choices}

It is widely accepted in the political literature that political participant awareness is a key determinant in the quality of the political system because a well-informed individual makes efficient political choices, which leads to efficient political results. Whereas individuals with the lowest levels of awareness are more likely to make inefficient decisions, resulting in inefficient outcomes. Therefore, wellinformed participation is mandatory for the generation of political value for efficient political results and effective political choices.

We put together political awareness and political involvement for each level of schooling to see how involved people in Rahim Yar Khan are in quality political participation and were surprised to find a significant gap between the two. We found individuals without education are more participative yet have a lesser degree of awareness, as seen in Figure 5. This significant participation by the least informed and least learned people raised genuine worries about the nature of their political decisions for significant and proficient political results and explained why the Political System isn't creating an incentive for individuals of Rahim Yar Khan regardless of huge support.

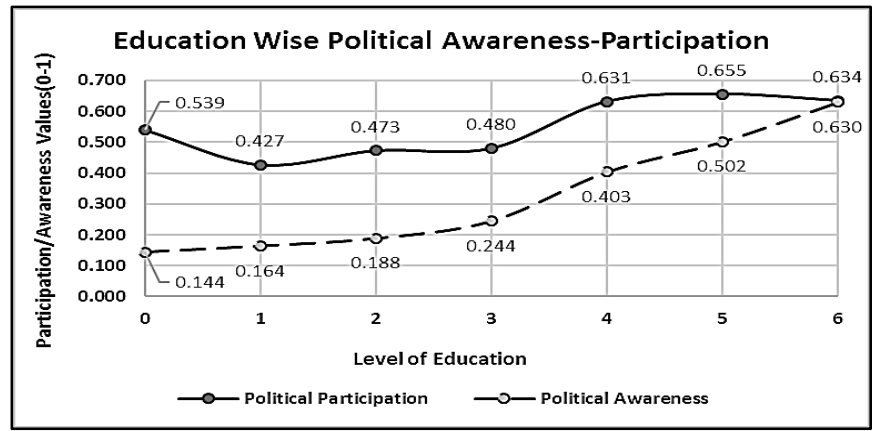

Fig. 5 Political awareness \& Participation by education

As shown in Figure 5, the gap between political participation and awareness at each educational level indicates that people participate in the political system in traditional and unconventional ways, but without a proper understanding of Political Dynamics, including the political structure and political representatives. As previously stated, the majority of those polled in this study were unaware of the names of their local political representatives, even at the lowest levels of the political structure (their local councilors). Individuals used to support or vote for political candidates without knowing their background, such as their name, education, profession, and, in some cases, political parties. This situation raises severe doubts regarding the quality of their selection. Individuals with a more significant lack of knowledge are more prone to make poor political decisions and make the same mistakes repeatedly. This gap validates the Rahim Yar Khan District scenario, where the Political Status Quo is reaping the benefits of ignorance by wielding political power even though the people of Rahim Yar Khan have no socio-economic value.

According to our findings, the biggest risk of making poor political decisions exists at level 0 education, when a 40 percent difference exists between political awareness (0.144) and political participation (0.539), as seen in Figure 6. This is particularly alarming in the instance of Rahim Yar Khan District, where 67 percent of the populace makes political decisions based on a lack of knowledge. The entire society of Rahim Yar Khan is now dealing with the consequences of these rash decisions in terms of an inefficient political status quo that has failed to generate social and economic value for the Rahim Yar Khan population for the past seven decades.

The second question is whether education has the ability or strength to close the gap. Yes, education can overcome this gap by boosting individuals' awareness levels, according to our findings. When compared to each level of education, the gap between political awareness and political participation narrows significantly as education levels climb, eventually disappearing entirely for those with level 6 education, as illustrated in Figure 6. 


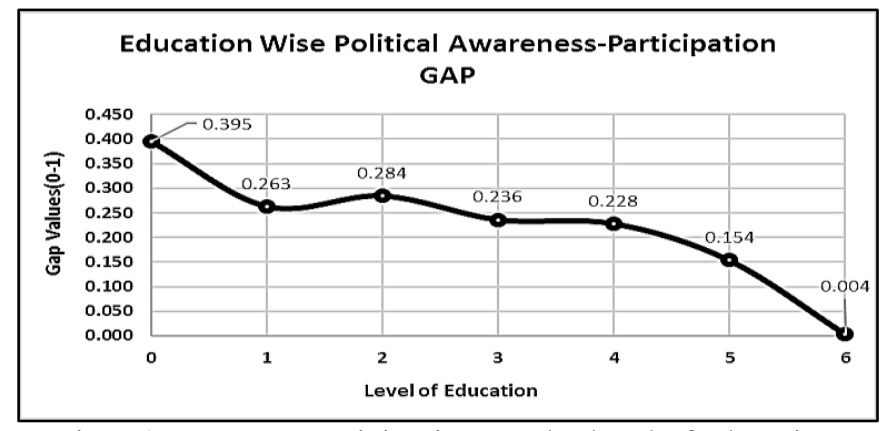

Fig. 6Awareness-Participation gap by level of education

With each increase in education, the possibility of wellinformed, efficient political engagement increases and hence increases the chance of rational political choices.

\section{CONCLUSION}

According to the recent advancements in academia, the development of a state crucially hinges upon the political, economic, and social institutions it has. With comprehensive analysis from the institutional researcher, the political institutions occupy a central place in the whole discourse of development due to their forward and backward linkages with the other social and economic institutions. The nature of political institutions then defines the nature of economic and social institutions. It has been further enlightened in the theory that extractive institutions promote fragility and inefficiencies and hence are destructive for development. Inclusive institutions on the other hand, are found to be positively associated with long-lasting, sustainable growth and development. In the light of this, if political institutions are of extractive nature, they tend to promote extractive economic and social institutions and hence obstruct the development process. Thus, political institutions, being a triggering force for the strength and quality of social and economic development, are the core of development. Now, the nature of political institutions depends upon the quality of the political system it entails, explained by the quality of political stakeholders engaged. Rolling up the whole discourse, the quality of stakeholders/individuals involved in the political system actually defines the nature of political institutions and hence the path of development. In line with this observation, the present study tried to highlight this very important aspect of individual quality for the nature of political institutions and the path of development by considering the case of Rahim Yar Khan, one of the least developed, massively uneducated, and politically encapsulated districts in Punjab province of Pakistan. The study, by looking at the extent to which individuals are making rational and informed political choices, assessed the political awareness as well as political participation of individuals with varying levels of education. The assessment based on education was carried to analyze whether education has any impact on the quality of political choices or not. Another way, it has been considered to analyze the linkages between the fruitless political status quo with that massive uneducated population.
The assessment results surprisingly confirm our claims that lack of education is damaging the very nature of politics and hence overall development at Rahim Yar Khan through poor quality political choices explained by the massive lack of political awareness at the lower level of education. An extremely poor display of two facets of political awareness and higher willingness to participate by the uneducated and lower educated individuals highlight the major reason behind a stronghold of few political families despite no value for the public as apparent from the dismal state of socio-economics development. A visibly greater gap between the political awareness and political participation of individuals with no or lower level of education explains the poor quality of political participation by the residents of Rahim Yar Khan. It has been further seen that the gap of political awareness and participation reduces with an increase in educational level, explaining the positive role of education behind quality political choices.

Based on the whole analysis, we can conclude that it is basically the massive lack of education by the residents of Rahim Yar Khan, which is responsible for the inefficient, unproductive political status quo and hence lack of development. On a cautious note, we can further conclude that the massive population at Rahim Yar Khan is kept uneducated intentionally to support and strengthening the stronghold of few political parties. Coherent with the whole analysis, the study has shown the importance of education towards the quality of political choice. Study in the light of whole analysis, thus, recommends an educational emergency on the war footing grounds at Rahim Yar Khan and the similar areas, if Pakistan wants to have well-aware quality political agents and hence long-lasting, stable, efficient, and productive political as well as socio-economic institutions. The state needs to invest heavily in the educational infrastructure to facilitate the education of uneducated individuals and hence sustainable growth and development in every domain.

Given the financial constraints which restricts the collection more data, the study tried to highlight the importance of education for well aware political participation. This is important for the less developed democracies like Pakistan to realize the significance of education for reaping the benefits of democracy for the long-term growth and development. One of the key problems facing most of the less developed states is the extractive political systems, strong prevalence of fruitless political status quo and exclusion of common from every stage of political and hence socio-economic decision making. This research has successfully shown that one of the most important determinants of such a passive and extractive political system is the lack of awareness and hence lack of rational political choices. For further analysis the study suggests an examination of individual freedom to involve in political system directly or indirectly in relation to individual education level. The main idea here is to look at whether education improve the perspectives of individuals to 
participate effectively. Future research may focus on the analysis of improvements in the socio-economic parameters having great influence on the freedom of individuals to effectively involve in political system. One can look at the economic freedom, offering more resources, social freedom based on the personal, family, religious and societal conditions, and availability of participatory opportunities, associated with better education.

\section{References}

[1] Albacete, G., \& Gema. (2014). Young People's Political Participation in Western Europe. Palgrave Studies in European Political Sociology.

[2] Berinsky, A. J., \& Lenz, G. S. (2011). Education and Political Participation:Exploring the Causal Link. Polit Behav, 33, 357-373.

[3] Brody, R. (1978). The puzzle of political participation in America. In A. King, The New American Political System. Washington, DC: American Enterprise Institute.

[4] Bryman, A. (2016). Social Research Methods. Oxford University Press.

[5] Conge, P. (1988). The concept of political participation: Toward a definition. Comparative Politics, 20(2), 241-249.

[6] Dee, T. (2004). Are there civic returns to education? Journal of Public Economics, 88, 1697-1720.

[7] Deth, J. W. (2014). A conceptual map of political participation. Acta Politica, 49(3), 349-367.

[8] GOP. (2016). Punjab Development Statistics. Government of Punjab.

[9] GOP. (2017). Punjab Development Statistics. Government of Punjab.

[10] GOP. (2021). Punjab Assembly Past Members Database 1947-2018. Retrieved from www.pap.gov.pk: https://www.pap.gov.pk/en/members/past-members

[11] Hay, C. (2007). Why we hate politics? Cambridge and Malden, MA: Polity Press.

[12] Hooghe, M., \& Quintelier, E. (2014). Political participation in European countries: The effect of authoritarian rule, corruption, lack of good governance and economic downturn. Comparative European Politics, 12(2), 209-232.

[13] Inglehart, R., \& Catterberg, G. (2002). Trends in Political Action: The Developmental Trend and the Post-Honeymoon Decline. International Journal of Comparative Sociology, 43(3-5), 300-316.

[14] Kaase, M., \& Marsh, A. (1979). Political action: A theoretical perspective. In S. H. Barnes, M. Kaase, \& K. R, Political Action: Mass Participation in Five Western Democracies.

[15] Kam, C., \& Palmer, C. (2008). Reconsidering the effects of education on political participation. The Journal of Politics, 70(3), 612-631.

[16] Milligan, K., Moretti, E., \& Oreopoulos, P. (2003). Does education improve citizenship? Evidence from the U.S. and U.K.
[17] National-Assembly-Pakistan. (2021). National Assembly Members List 1954-2018. Retrieved from www.na.gov.pk:

http://www.na.gov.pk/en/content.php?id=121

[18] OSTROM, E. (2015). GOVERNING THE COMMONS: The evolution of institutions for collective action. Cambridge University Press.

[19]Pateman, C. (2012). Participatory Democracy Revisited. Perspectives on Politics, 10(1), 7-19.

[20]PBS. (2017). Rahim Yar Khan District Census Report, 2017. Pakistan Bureau of Statistics.

[21] Robinson, J. A., \& Acemoglu, D. (2012). Why Nations Fail? Crown Publishing Group.

[22] Rosenstone, S., \& Hansen, J. (1993). Mobilization, participation, and democracy in America. . New York: Macmillan Publishing Company.

[23] Sondheimer, R., \& Green, D. (2010). Using experiments to estimate the effects of education on voter turnout. American Journal of Political Science, 54(1), 174-189.

[24] Tenn, S. (2007). The effect of education on voter turnout. Political Analysis, 15(4), 446-464.

[25] Teorell, J. (2010). Determinants of Democratization: Explaining Regime Change in the World, 1972-2006. Cambridge: Cambridge University Press.

[26]UNDP. (2017). Pakistan National Human Development Report 2017: Unleashing the Potential of Young Pakistan. United Nations Development Program, Pakistan.

[27] Verba, S., Schlozman, K., \& Brady, H. (1995). Voice and equality: Civic voluntarism in American politics. Cambridge: Cambrige University Press.

[28]Zukin, C., Keeter, S., Andolina, M., Jenkins, K., \& Carpini, M. D. (2006). A New Engagement? Political Participation, Civic Life, and the Changing American Citizen. Oxford: Oxford University Press.

\section{Creative Commons Attribution License 4.0 (Attribution 4.0 International, CC BY 4.0)}

This article is published under the terms of the Creative Commons Attribution License 4.0 https://creativecommons.org/licenses/by/4.0/deed.en US 
INTERNATIONAL JOURNAL OF EDUCATION AND INFORMATION TECHNOLOGIES

APPENDIX

Table 1. Distribution of respondents by level of education

\begin{tabular}{|c|c|c|c|c|c|c|c|c|}
\hline MALE & Less Than Primary & Primary & Middle & Matric & Intermediate & Bachelor & Masters and Higher & Total \\
\hline $25-29$ & 15 & 27 & 22 & 23 & 9 & 5 & 2 & 102 \\
\hline $30--34$ & 13 & 23 & 17 & 15 & 6 & 4 & 2 & 79 \\
\hline $35-39$ & 8 & 15 & 14 & 11 & 3 & 2 & 1 & 56 \\
\hline $40-44$ & 8 & 13 & 11 & 10 & 3 & 2 & 1 & 48 \\
\hline $45-49$ & 7 & 11 & 7 & 7 & 2 & 2 & 1 & 36 \\
\hline $50--54$ & 6 & 9 & 6 & 5 & 2 & 1 & 1 & 30 \\
\hline $55-59$ & 4 & 6 & 4 & 3 & 1 & 1 & 1 & 20 \\
\hline Total & 61 & 103 & 82 & 75 & 26 & 17 & 8 & 372 \\
\hline FEMALE & Less Than Primary & Primary & Middle & Matric & Intermediate & Bachelor & Masters and Higher & \\
\hline $25-29$ & 1 & 1 & 1 & 1 & 1 & 1 & 1 & 7 \\
\hline $30-34$ & 1 & 1 & 1 & 1 & 1 & 1 & 1 & 7 \\
\hline $35-39$ & 1 & 1 & 1 & 1 & 1 & 1 & 1 & 7 \\
\hline $40-44$ & 1 & 1 & 1 & 1 & 1 & 1 & 1 & 7 \\
\hline $45-49$ & 1 & 1 & 1 & 1 & 1 & 1 & 1 & 7 \\
\hline $50-54$ & 1 & 1 & 1 & 1 & 1 & 1 & 1 & 7 \\
\hline $55-59$ & 1 & 1 & 1 & 1 & 1 & 1 & 1 & 7 \\
\hline Total & 7 & 7 & 7 & 7 & 7 & 7 & 7 & 49 \\
\hline Grand Total & 68 & 110 & 89 & 82 & 33 & 24 & 15 & 421 \\
\hline
\end{tabular}

*Based on the proportions extracted from Age-education population distribution as per Rahim Yar Khan District Census Report, 2017 
INTERNATIONAL JOURNAL OF EDUCATION AND INFORMATION TECHNOLOGIES

Table 2. List of Union Councils Visited for Survey

\begin{tabular}{|c|c|c|c|c|c|c|c|c|c|c|c|}
\hline S.No & Tehsil & Union Council Name & S.No & Tehsil & Union Council Name & S.No & Tehsil & Union Council Name & S.No & Tehsil & Union Council Name \\
\hline 1 & RYK & ABADPUR & 32 & RYK & U.C-B Rahim Yar Khan & 63 & $L P$ & TRINDA GURGAJ & 94 & SA & U.C-F SADIQABAD \\
\hline 2 & RYK & AKRAMABAD & 33 & RYK & U.C-C Rahim Yar Khan & 64 & LP & TRINDA MUHAMMAD PANNAH & 95 & KP & AZIMSHAH \\
\hline 3 & RYK & AMIN GARH & 34 & RYK & U.C-D Rahim Yar Khan & 65 & LP & ZAFAR ABAD & 96 & $\mathrm{KP}$ & BGHO BAHAR \\
\hline 4 & RYK & AMIN GARH. & 35 & RYK & U.C-E Rahim Yar Khan & 66 & SA & ADAM SOHABA & 97 & KP & CHACHRAN SHARIF \\
\hline 5 & RYK & BADLI SHARIF & 36 & RYK & U.C-F Rahim Yar Khan & 67 & SA & AHMADPUR LAMMA & 98 & $\mathrm{KP}$ & CHAK NO.45/P \\
\hline 6 & RYK & BAHDIPUR QURESHIAN & 37 & RYK & U.C-G Rahim Yar Khan & 68 & SA & AHMEDPUR LAMA (URBAN) & 99 & $\mathrm{KP}$ & CHANDIA. \\
\hline 7 & RYK & BAHISHTI & 38 & RYK & U.C-H Rahim Yar Khan & 69 & SA & BHONG & 100 & $\mathrm{KP}$ & DINPUR SHARIF \\
\hline 8 & RYK & BULAQI WALI & 39 & RYK & U.C-I Rahim Yar Khan & 70 & SA & BHUTTA WAHAN & 101 & $\mathrm{KP}$ & GHARI IFTIKHAR KHAN \\
\hline 9 & RYK & CHAK N0.105/P & 40 & RYK & WAH KHUNA & 71 & SA & CHAK NO.160/P & 102 & $\mathrm{KP}$ & GHAZIPUR \\
\hline 10 & RYK & CHAK NO.139/P & 41 & LP & AHMAD ALI LAR & 72 & SA & CHAK NO.173/P & 103 & $\mathrm{KP}$ & GHENA LAR (H.Q.JANGI) \\
\hline 11 & RYK & CHAK NO.228/P & 42 & LP & ALLAH ABAD. & 73 & SA & CHAK NO.264/P & 104 & $\mathrm{KP}$ & ISLAMGARH \\
\hline 12 & RYK & CHAK NO.51/P & 43 & LP & AMINABAD & 74 & SA & DHANDI & 105 & KP & JAJJA ABBASIAN \\
\hline 13 & RYK & CHAK NO.84/P & 44 & LP & CHAK NO.10 ABBASIA & 75 & SA & DRIGRA & 106 & KP & JETHA BHUTTA \\
\hline 14 & RYK & DAARI AZIM KHAN & 45 & LP & CHAK NO.178/7-R & 76 & SA & GOTH JANGOO & 107 & $\mathrm{KP}$ & JHORAN \\
\hline 15 & RYK & GALOR MASU KHAN & 46 & LP & CHAK NO.42 ABBASIA & 77 & SA & JAMAL DIN WALI & 108 & KP & KOTLA PATHAN \\
\hline 16 & RYK & HAJIPUR & 47 & LP & CHAK NO.46 ABBASIA & 78 & SA & KOT SANJAR KHAN & 109 & $\mathrm{KP}$ & LATKI \\
\hline 17 & RYK & KOT MEHDI SHAH & 48 & LP & CHAK NO.68 ABBASIA & 79 & SA & MACHKA & 110 & $\mathrm{KP}$ & MARI ALLAH BACHAYA \\
\hline 18 & RYK & KOT SAMABA & 49 & LP & CHANJNI & 80 & SA & MOHIB SHAH & 111 & $\mathrm{KP}$ & MUD BHOORA \\
\hline 19 & RYK & MAU MUBARIK & 50 & LP & DESHTI & 81 & SA & MUHAMMADPUR & 112 & $\mathrm{KP}$ & MUEENABAD \\
\hline 20 & RYK & MIAN WALI QURESHIAN & 51 & LP & DULLI KABIR KHAN & 82 & SA & NAWAZABAD & 113 & KP & NAWAN KOT \\
\hline 21 & RYK & MIANWALI SHEIKHAN & 52 & LP & GHOOKA & 83 & SA & RAHIMABAD & 114 & KP & NEEL GARH \\
\hline 22 & RYK & MURTAZABAD & 53 & LP & GUL MUHAMMAD LANGAH & 84 & SA & RANJEH KHAN & 115 & KP & QADIRPUR. \\
\hline 23 & RYK & RAHIMYRA KHAN DEH & 54 & LP & HAYATLAR & 85 & SA & RASOOLPUR. & 116 & $\mathrm{KP}$ & SEHA \\
\hline 24 & RYK & RAJANPUR & 55 & LP & JAN PUR & 86 & SA & ROSHAN BHAIT & 117 & KP & U.C-A KHAN PUR \\
\hline 25 & RYK & SHAHPUR. & 56 & LP & JHOKE GULAB SHAH & 87 & SA & SADIOABAD DEH & 118 & KP & U.C-B KHAN PUR \\
\hline 26 & RYK & SHAREEN (KOT KARAM KHAN & 57 & LP & KHAN BELA & 88 & SA & SANJARPUR & 119 & KP & U.C-C KHAN PUR \\
\hline 27 & RYK & SONAK & 58 & LP & LIAQATPUR & 89 & SA & U.C-A SADIOABAD & 120 & $\mathrm{KP}$ & U.C.D KHAN PUR \\
\hline 28 & RYK & THUL KHAIR & 59 & LP & MUHAMMAD DAHA & 90 & SA & U.C-B SADIOABAD & 121 & $\mathrm{KP}$ & U.C-E KHAN PUR \\
\hline 29 & RYK & TIBI GUL MUHAMMAD & 60 & $L P$ & MULA MUSANI & 91 & SA & U.C-C SADIQABAD & 122 & KP & ZAHIR PIR \\
\hline 30 & RYK & TRANDA SAWAY KHAN & 61 & LP & PACCA LARAN & 92 & SA & U.C-D SADIOABAD & & & \\
\hline 31 & RYK & U.C-A Rahim Yar Khan & 62 & LP & SHEDANI SHARIF & 93 & SA & U.C-E SADIOABAD & & & \\
\hline
\end{tabular}

*Based on the proportions extracted from Age-education population distribution as per Rahim Yar Khan District Census Report, 2017 
Table 3. Items for Awareness of Political System Assessment

\begin{tabular}{|c|c|}
\hline Category & Item \\
\hline \multirow{8}{*}{ Composition } & [Total No of seats in National Assembly] \\
\hline & [General Seats in National Assembly] \\
\hline & [Minority Seats in National Assembly] \\
\hline & [Women Reserve Seats in the National Assembly] \\
\hline & [No of National Assembly Seats in Your District] \\
\hline & [Total No of seats in Provincial Assembly of your province] \\
\hline & [No of Provincial Assembly Seats in your District] \\
\hline & [Total no of seats in Senate of Pakistan] \\
\hline \multirow{4}{*}{ Stakeholders } & [Name of the Opposition Leader in last Assembly.] \\
\hline & [Name of the Speaker in last National Assembly] \\
\hline & [Name of the Chairman Senate] \\
\hline & [Name of Governor in your Province] \\
\hline \multirow{5}{*}{ Functional Attributes } & [Tenure of a Member National Assembly] \\
\hline & [Minimum Age for the member of National Assembly] \\
\hline & [Tenure of a Senator] \\
\hline & [SMS Code to know your voter's profile] \\
\hline & [Minimum age of voter] \\
\hline
\end{tabular}

Table 4. Individual Responses for Conventional Political Participation (\%)

\begin{tabular}{|c|c|c|c|c|c|}
\hline \multirow[b]{2}{*}{ Education } & \multicolumn{5}{|c|}{ Q1: What chances are there for you to Vote in next elections? } \\
\hline & 0-No Chance & $\begin{array}{l}\text { 1-Minor } \\
\text { Chance }\end{array}$ & 2-Moderate Chance & 3-High Chance & 4-Definitly \\
\hline 0 & 12.24 & 6.12 & 2.04 & 10.20 & 69.39 \\
\hline 1 & 8.57 & 8.57 & 5.71 & 28.57 & 48.57 \\
\hline 2 & 3.66 & 1.22 & 1.22 & 21.95 & 71.95 \\
\hline 3 & 2.47 & 2.47 & 3.70 & 29.63 & 61.73 \\
\hline 4 & 0.00 & 0.00 & 0.00 & 11.11 & 88.89 \\
\hline 5 & 3.45 & 3.45 & 6.90 & 10.34 & 75.86 \\
\hline 6 & 0.00 & 2.94 & 5.88 & 16.99 & 74.18 \\
\hline \multirow{2}{*}{$\begin{array}{c}\text { Education } \\
\text { Level }\end{array}$} & \multicolumn{5}{|c|}{$\begin{array}{l}\text { Q2: What chances are there for you to campaign in election for some political } \\
\text { party/leader? }\end{array}$} \\
\hline & 0-No Chance & $\begin{array}{l}\text { 1-Minor } \\
\text { Chance }\end{array}$ & 2-Moderate Chance & 3-High Chance & 4-Definitly \\
\hline 0 & 46.94 & 4.08 & 4.08 & 12.24 & 32.65 \\
\hline 1 & 41.90 & 22.86 & 9.52 & 19.05 & 6.67 \\
\hline 2 & 51.22 & 7.32 & 7.32 & 23.17 & 10.98 \\
\hline 3 & 48.15 & 9.88 & 7.41 & 20.99 & 13.58 \\
\hline 4 & 22.22 & 13.89 & 8.33 & 38.89 & 16.67 \\
\hline 5 & 20.69 & 0.00 & 6.90 & 48.28 & 24.14 \\
\hline 6 & 39.87 & 5.88 & 14.71 & 5.88 & 33.66 \\
\hline \multirow[b]{2}{*}{$\begin{array}{c}\text { Education } \\
\text { Level }\end{array}$} & \multicolumn{5}{|c|}{ Q3: What chances are there for you to donate for some political party/leader. } \\
\hline & 0-No Chance & $\begin{array}{l}\text { 1-Minor } \\
\text { Chance }\end{array}$ & 2-Moderate Chance & 3-High Chance & 4-Definitly \\
\hline 0 & 63.27 & 6.12 & 2.04 & 8.16 & 20.41 \\
\hline 1 & 60.95 & 16.19 & 4.76 & 11.43 & 6.67 \\
\hline 2 & 71.95 & 3.66 & 4.88 & 14.63 & 4.88 \\
\hline 3 & 67.90 & 9.88 & 1.23 & 7.41 & 13.58 \\
\hline 4 & 44.44 & 13.89 & 0.00 & 22.22 & 19.44 \\
\hline 5 & 48.28 & 3.45 & 6.90 & 24.14 & 17.24 \\
\hline 6 & 48.69 & 11.44 & 8.82 & 5.88 & 25.16 \\
\hline
\end{tabular}


Table 5. Individual Responses for Unconventional Political Participation

\begin{tabular}{|l|l|l|l|l|l|}
\hline \hline \multirow{2}{*}{ Education Level } & \multicolumn{5}{|l|}{ Q1: What chances are there for you to participate in protest against political issues? } \\
\cline { 2 - 6 } & $\mathbf{0 - N o}$ Chance & l-Minor Chance & 2-Moderate Chance & 3-High Chance & 4-Definitly \\
\hline 0 & 34.69 & 4.08 & 6.12 & 4.08 & 51.02 \\
\hline 1 & 43.81 & 21.90 & 16.19 & 8.57 & 9.52 \\
\hline 2 & 43.90 & 9.76 & 7.32 & 18.29 & 20.73 \\
\hline 3 & 53.09 & 11.11 & 6.17 & 12.35 & 17.28 \\
\hline 4 & 41.67 & 11.11 & 5.56 & 16.67 & 25.00 \\
\hline 5 & 37.93 & 3.45 & 6.90 & 20.69 & 31.03 \\
\hline 6 & 28.76 & 5.88 & 11.44 & 14.38 & 39.54 \\
\hline \multirow{2}{*}{ Education Level } & Q2: What chances are there for you to lead your community for conveying political \\
& problems to the concerned political authorities? & & \\
\cline { 2 - 6 } & $\mathbf{0 - N o}$ Chance & $\mathbf{1 - M i n o r}$ Chance & $\mathbf{2 - M o d e r a t e ~ C h a n c e ~}$ & $\mathbf{3 - H i g h ~ C h a n c e ~}$ & 4-Definitly \\
\hline 0 & 34.69 & 8.16 & 6.12 & 4.08 & 46.94 \\
\hline 1 & 18.10 & 18.10 & 9.52 & 31.43 & 22.86 \\
\hline 2 & 30.49 & 8.54 & 4.88 & 28.05 & 28.05 \\
\hline 3 & 23.46 & 2.47 & 6.17 & 32.10 & 35.80 \\
\hline 4 & 8.33 & 0.00 & 0.00 & 36.11 & 55.56 \\
\hline 5 & 3.45 & 3.45 & 3.45 & 34.48 & 55.17 \\
\hline 6 & 11.44 & 0.00 & 5.88 & 23.20 & 59.48 \\
\hline \hline
\end{tabular}

